\title{
Analysis of Student Problem-Solving Ability Topics 3D Reviewed from Geometry Thinking Level
}

\author{
Bagas Ardiyanto*, Gunawan, Maryam Abdulloh, Safrilia Septiasari \\ Mathematics Education Study Program, Faculty of Theacher Training and Education, Tidar University, \\ Jl. Kapten Suparman 39 Magelang 56116, Indonesia. Tel. (0293) 364113, Fax. (0293) 362438. \\ Email*: bagasardiyanto122@gmail.com
}

\begin{abstract}
Each student has different problem-solving skills on the 3D topic. The study aims to find out the student problem-solving skills in the 3D Topics reviewed from geometry thinking level. This type of research is qualitative research with a case study approach. The subject in this study is as many as 20 subjects consisting of high problem-solving capabilities, moderate problem-solving capabilities, and low problem-solving capabilities. The data collection Instrument on this research is a level test of geometry thinking. The results showed that students in the category of high problem-solving skills were able to master level 0, Level 1, Level 2, and level 3 despite not being perfect, students in the category of problem-solving skills were able to master level 0, Level 1, and Level 2, students in the category of low problem-solving skills are only capable of mastering level 0 and Level 1.
\end{abstract}

Keywords: Problem-solving capabilities, 3D, geometry thinking levels

\section{INTRODUCTION}

The word "math" derives from the Greek word mathema, which translates as "science, science, or learning", as well as Mathematicos which means "like learning". Mathematics is one of the basic lessons learned at every level of the school, ranging from elementary school, junior high, to high school. This is because mathematics plays an important role in solving daily life. James and James (1976) in Suherman (2001:140) suggest that mathematics is a science of logic about the form, arrangement, magnitude, and concepts associated with each other with a lot of numbers divided into three areas namely: algebra, analysis, and geometry.

Geometry is one part of mathematics science that learns points, lines, builds, relationships between lines, length, area, volume, etc. (Baykul in Biber, 2013). Geometry learning can also increase child interest in mathematics, improve problem-solving skills, reasoning and ease in learning various mathematical and scientific topics. One of the learning geometry is the theory of Van Hiele or commonly called the level of geometry thinking. The stages of the geometry think according to Van Hiele are five stages of visualization, analysis stage, formal deduction stage, deduction stage, and rigor stage. One of the geometric material studied by the class XII IPA is dimension three. 3D material is material that is difficult to understand because it is abstract and lack of the skills of the students in drawing a 3D wake-up. The weak mastery of geometry material in the three possibilities is caused by understanding the concept of students who are not maximally.

One of the ways to develop students abilities is with problem-solving skills. According to Siswono (suci and
Rosyidi, 2012), problem-solving is an individual process or effort to respond to or overcome obstacles or constraints when an answer or method of the answer is not yet apparent. According to Polya elaborates in detail about the four stages of problem-solving, which are presented in order, namely: (1) Understanding the problem, in this step students must find what is known and what is asked in the problem or that given. (2) Devising a plan, after understanding the problem that is given next student to develop a solution plan. (3) Carrying out the plan, the plan that has been compiled next can be used to solve the problem by implementing the plan that has been created. (4) Looking back (reexamining the process and outcome) results obtained from carrying out the plan, the student must re-check the answers.

\section{MATERIAL AND METHODS}

This research is a qualitative study with a case study approach. The subject in the study was a grade XII student of SMA Islam Secang consisting of 20 students and had traveled 3D material. The instrument in this study was a matter of the problem-solving capability of the 3D matter material that contains the level of geometry thinking.

Researchers have given questions about the problemsolving capability of the 3D matter of 8 questions with the type of problem that contains the level of geometry thinking. Then the result of the subject work will be categorized into Three, which are students with low problem-solving skills, students with moderate problemsolving skills, and students with high problem-solving 
abilities. The level of problem-solving capability is based on the outcome of each student's value with the benchmark students who have high problem-solving skills are students who have a value with a range of 80 100 , students who have moderate problem-solving skills are students who have a value with a range of 50-75, and students who have low problem ability are students who have values with a range of $<50$. From this categorizing can be analytic on the level of geometry thinking.

Table 1. Van Hiele Thinking level indicator.

\begin{tabular}{|c|c|c|c|}
\hline No. & Thinking Level & Dimensions & Indicator \\
\hline 1. & Level 0 (visualization) & $\begin{array}{l}\text { 1) Identifying the building of } 3 \mathrm{D} \text { space. } \\
\text { 2) Sorting } 3 \mathrm{D} \text { buildings. } \\
\text { 3) Draw or copy up space as well as } \\
\text { identifying parts of the image. }\end{array}$ & $\begin{array}{l}\text { 1) Students can identify waking up based on the } \\
\text { shape he has seen in full. } \\
\text { 2) Students can specify an example and which is not } \\
\text { an example of an image build geometry. } \\
\text { 3) Students can draw or copy the shape of the wake- } \\
\text { up space as well as identify parts of the image. }\end{array}$ \\
\hline 2. & Level 1 (Analysis) & $\begin{array}{l}\text { 1) Identifying projection on a three- } \\
\text { dimensional space build. } \\
\text { 2) Determining point and Line projection } \\
\text { on fields in three-dimensional space. }\end{array}$ & $\begin{array}{l}\text { 1) Students can describe the projection of points } \\
\text { and lines on the field in the building space. } \\
\text { 2) Students can compare the projection point on the } \\
\text { fields and lines on the field in the building space. } \\
\text { 3) Students can solve problems involving projection } \\
\text { points and lines on fields in the triple dimension } \\
\text { space. }\end{array}$ \\
\hline 3. & $\begin{array}{l}\text { Level } 2 \text { (Informal } \\
\text { deduction) }\end{array}$ & $\begin{array}{l}\text { 1) Defines the distance between points, } \\
\text { lines, and fields. } \\
\text { 2) Find and explain how to determine } \\
\text { point spacing, lines, and fields. }\end{array}$ & $\begin{array}{l}\text { 1) Students can compose a definition of distance } \\
\text { between points, lines and fields with their own } \\
\text { language. } \\
\text { 2) Students are able to understand the equivalence } \\
\text { form of a definition. } \\
\text { 3) Students are able to use an implication } \\
\text { statement/"if.. Then..." } \\
\text { 4) Students can solve problems involving point } \\
\text { spacing, lines and fields. }\end{array}$ \\
\hline 4. & Level 3 (deduction) & $\begin{array}{l}\text { 1) Comparing components of } \\
\text { mathematical statements in geometry. }\end{array}$ & $\begin{array}{l}\text { 1) Students can understand some mathematical } \\
\text { statements such as axioms, definitions, theorem, } \\
\text { and evidence. } \\
\text { 2) Students can compose the evidence in deductive. }\end{array}$ \\
\hline
\end{tabular}

The indicator level thinks Van Hiele in this 3D material is only presented up to Level 3 (deduction) taking into consideration that the study was conducted on class XII SMA so have not been able to understand the material at level 4 (rigor).

\section{RESULT AND DISCUSSION}

The research aims to identify the problem of solving the problems of class XII students of the School Islam Secang in 3D material by conducting an analysis of problem-solving skills reviewed from the level of geometry thinking. Based on research case studies in class XII students of SMA Islam Secang with the subject of 20 students divided into three categories of assessment of 5 students with a high level of problemsolving ability, 8 students with moderate problemsolving ability level, and 7 students with low problem ability levels. Then from this categorizing can be analyzed how the student's geometry thinking levels are highly problem-capable, students are moderate problem solving and students are low problem-solving.
Based on the research data of the subject with the students high problem-solving category, the students are moderate problem solving and the low problem-capable students are as follows.

\section{Students with low problem-solving capabilities a. Subject 1}

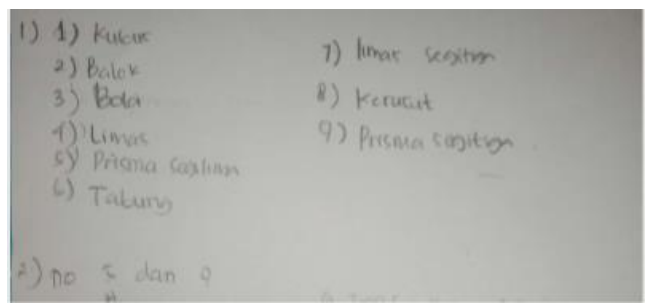

Based on the results of work numbers 1 and 2, it appears that subject 1 can solve the problem and it can be concluded that subject 1 can be in Level 0 (visualization). 


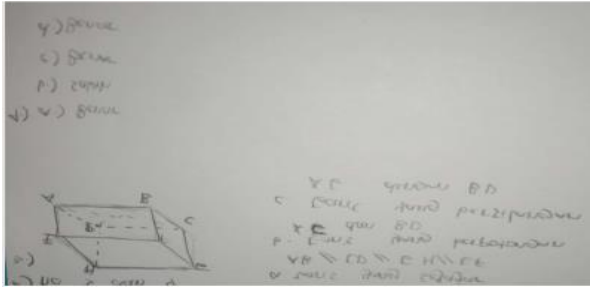

Based on the results of the work numbers 3 and 4, it appears that the subject 1 can solve the problem and can be concluded that the subject 1 can be in Level 1 (analysis).

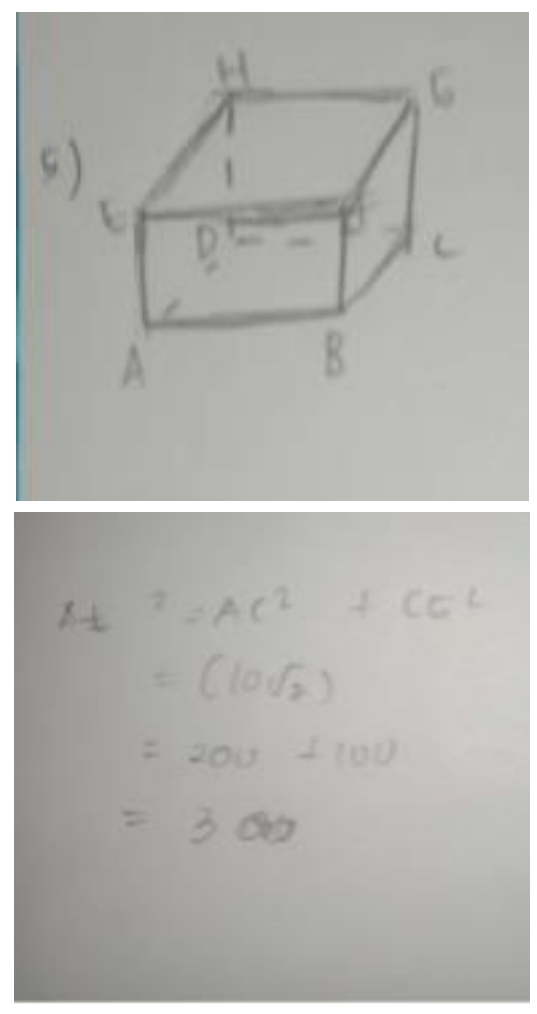

Based on the result of the work number 5, it appears that the answer from subject 1 is less precise, the answer should be $10 \sqrt{ } 2$, so it can be concluded that subject 1 less capable in Level 2 (informal deduction).

\section{b. Subject 2}

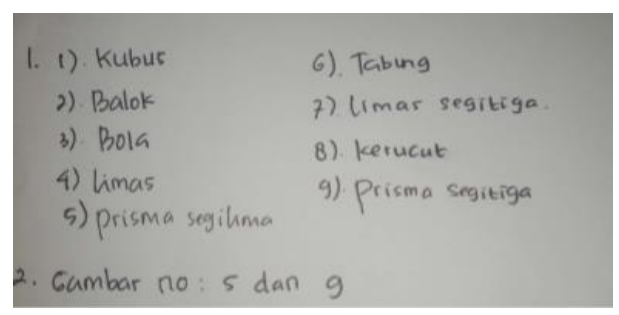

Based on the results of the work of the numbers 1 and 2 , it appears that the subject 2 can be in the matter and can be concluded that the subject 2 is capable of level 0 (visualization).

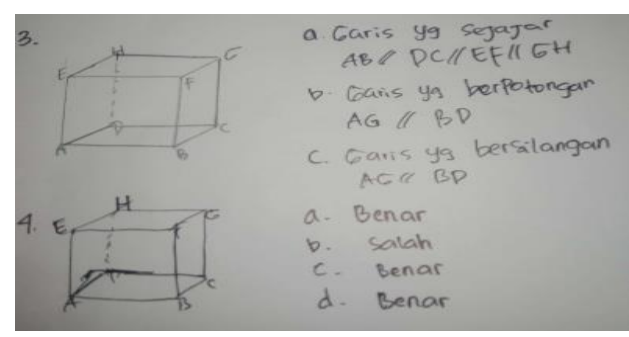

Based on the results of the work of the numbers 3 and 4 , it is shown that subject 2 can resolve the matter and it can be concluded that subject 2 can be in Level 1 (analysis).

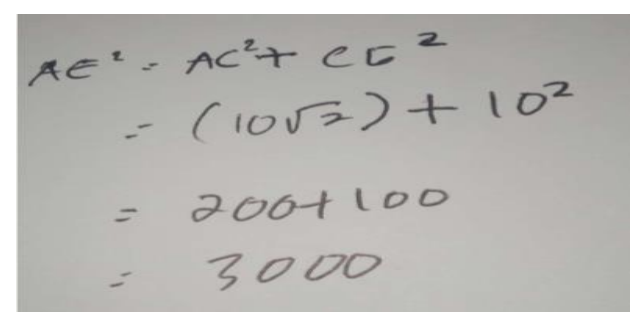

Based on the result of work number 5, it appears that subject 2 is not correct in answering the question, the answer should be $10 \sqrt{ } 2$. It can be concluded that subject 2 is less capable in Level 2 (informal deduction).

Based on the work of subject 1 and subject 2 with low problem-solving capabilities, they are able to complete level 0 (visualization) and Level 1 (analysis), but they are less capable of finishing on level 2 (informal deduction).

\section{Students with moderate problem-solving skills a. Subject 3}

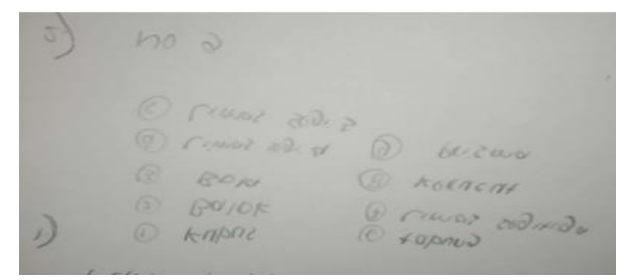

Based on the results of the work numbers 1 and 2, it is shown that the subject 3 is able to solve the problem and it can be concluded that the subject 3 is capable of level 0 (visualization).

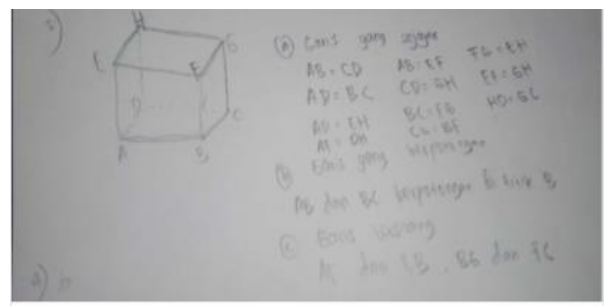

Based on the results of the work numbers 3 and 4, it is shown that the subject 3 can resolve the matter and it 
can be concluded that the subject of 3 is capable in Level 1 (analysis).
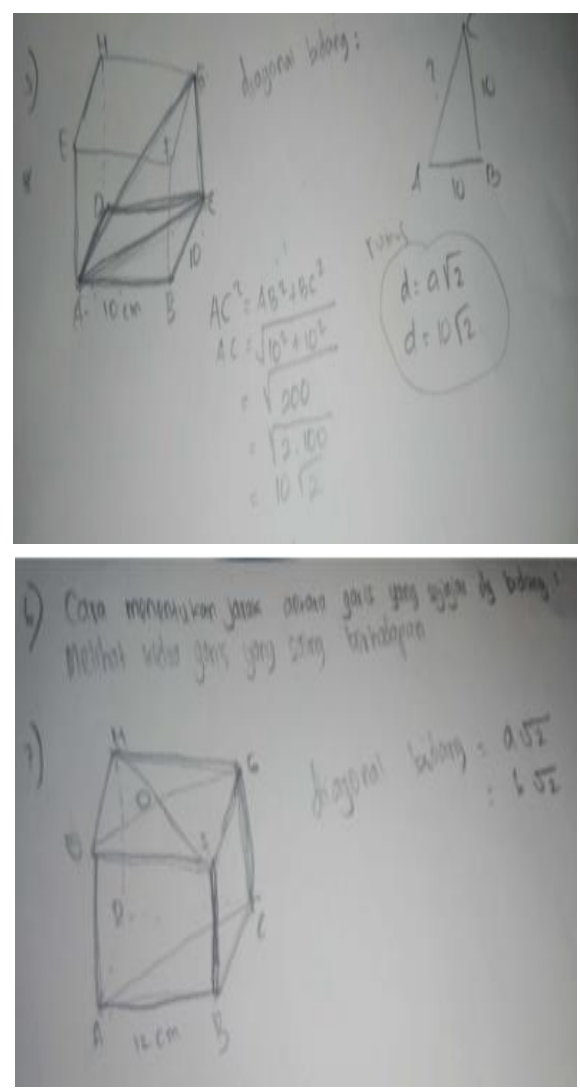

Based on the results of the work numbers 5, 6 and 7, it is shown that subject 3 can resolve the matter and it can be concluded that the subject of 3 is able to be in Level 2 (informal deduction).

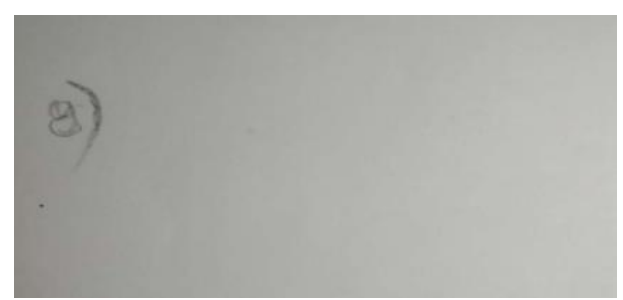

Based on the result of work number 8 , it is seen that subject 3 is not able to solve the problem or no work at all, so it can be concluded that the subject of 3 is not able in level 3 (deduction).

\section{b. Subject 4}

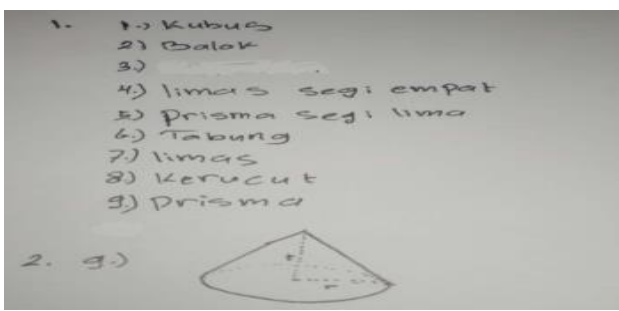

Based on the results of the work numbers 1 and 2, it is shown that subject 4 can solve the problem and it can be concluded that the subject of 3 is capable of level 0 (visualization).

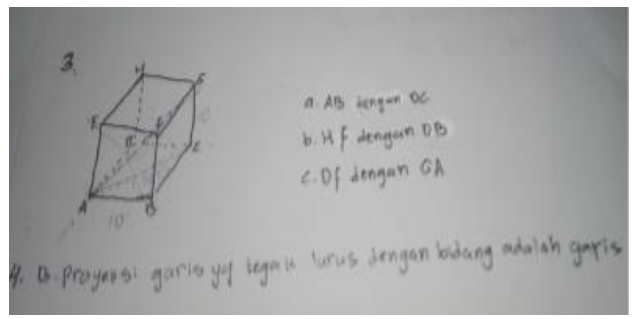

Based on the results of the work numbers 3 and 4, it is shown that subject 4 can resolve the matter and it can be concluded that the subject of 4 is capable in Level 1 (analysis).

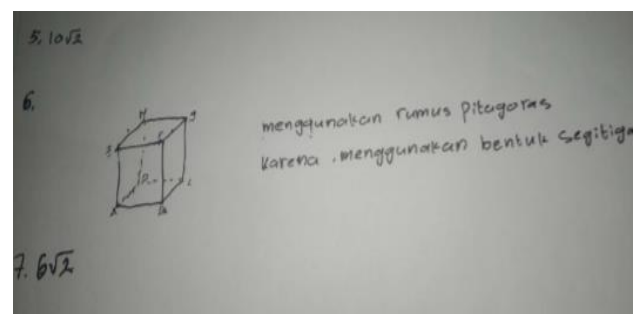

Based on the work of numbers 5, 6 and 7, it appears that the subject 4 only wrote the answer just not by way of completion but the answer of subject 4 is true. It can be concluded that subject 4 is capable of level 2 (informal deduction).

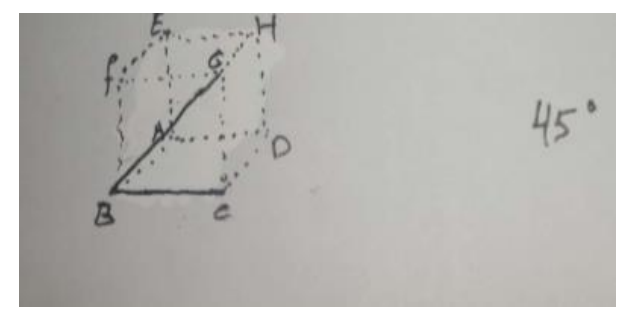

Based on the result of work numbers 8 , it is shown that subject 4 only describes its shape but not able to explain the victim. So it can be concluded that the subject 4 is less capable in Level 3 (deduction).

Based on the results of the work of subjects 3 and 4 who have moderate problem-solving capabilities, they are capable of level 0 (visualization), Level 1 (Analysis), Level 2 (informal deduction) but less capable in Level 3 (deduction). 


\section{Students with high problem-solving skills}

a. Subjek 5

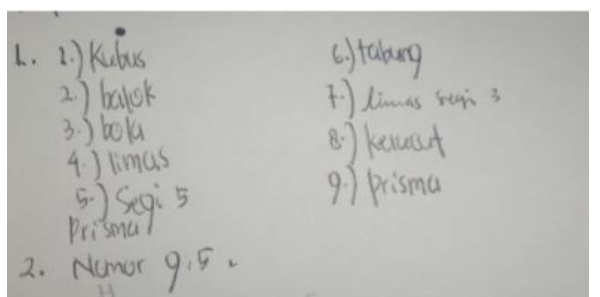

Based on the results of the work number 1 and 2, it is shown that the subject 5 can solve the problem and it can be concluded that the subject of 5 capable in level 0 (visualization).

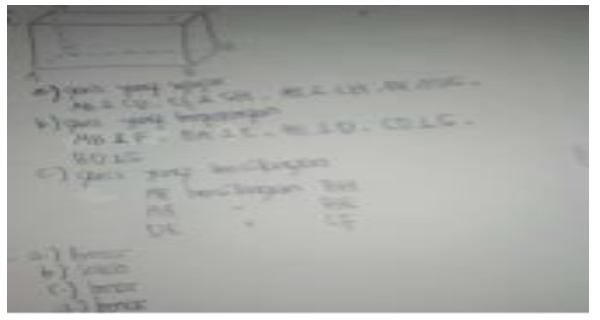

Based on the results of the work numbers 3 and 4 , it appears that the subject 5 can solve the problem and it can be concluded that the subject of 5 capable in Level 1 (analysis).
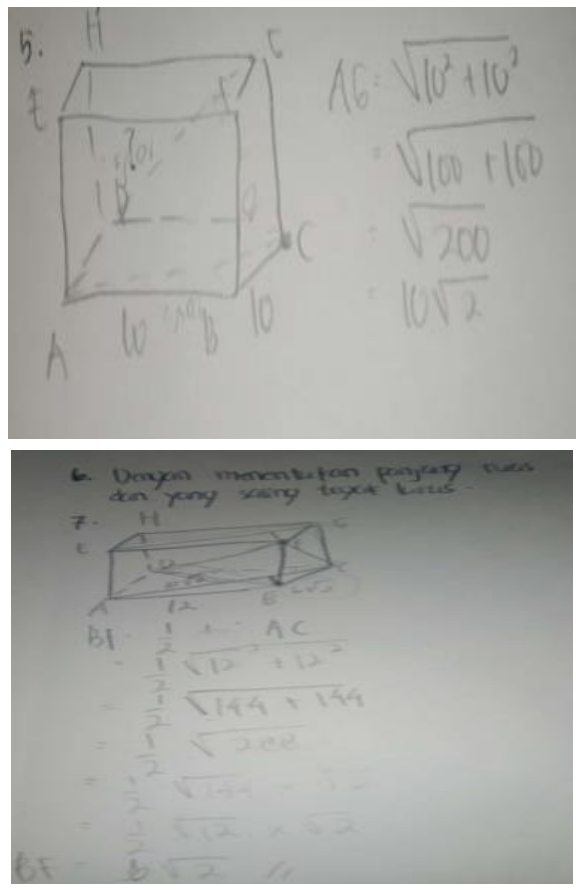

Based on the results of the work numbers 5, 6 and 7, it appears that the subject 5 can resolve the matter and can be concluded that the subject of 5 can be in Level 2 (informal deduction).

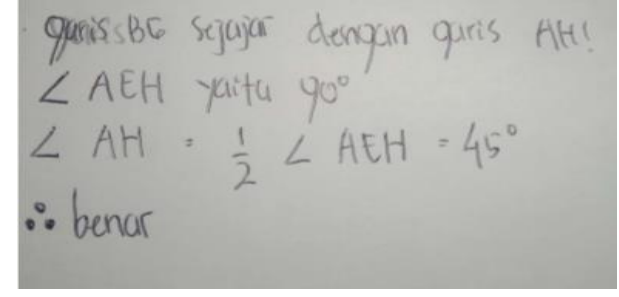

Based on the result of the work number 8 , it is seen that the subject 5 already understand the meaning of the problem but in the evidence is less widespread or too simple, it can be concluded that the subject 5 has begun to take off in the Level 3 (deduction) although not yet perfect.

\section{b. Subject 6}

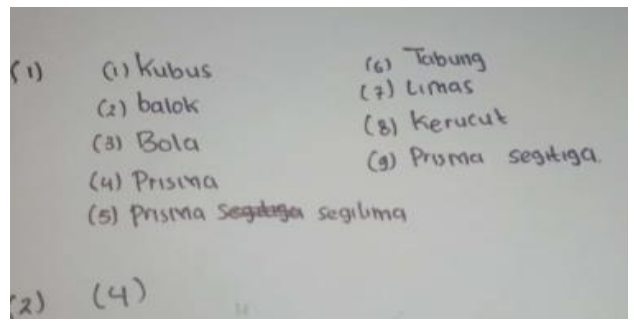

Based on the results of work numbers 1 and 2 , it is shown that the subject of 6 can solve the problem and it can be concluded that the subject of 6 is capable in level 0 (visualization).

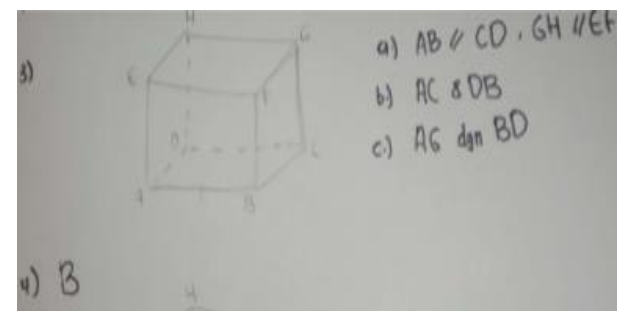

Based on the results of the work numbers 3 and 4, it is shown that the subject of 6 can resolve the matter and it can be concluded that the subject of 6 is capable in Level 1 (analysis).

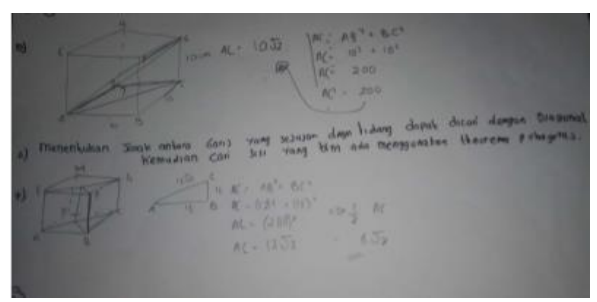

Based on the results of the work numbers 5, 6 and 7, it is seen that the subject of 6 can resolve the matter and can be concluded that the subject of 6 can be in Level 2 (informal deduction). 


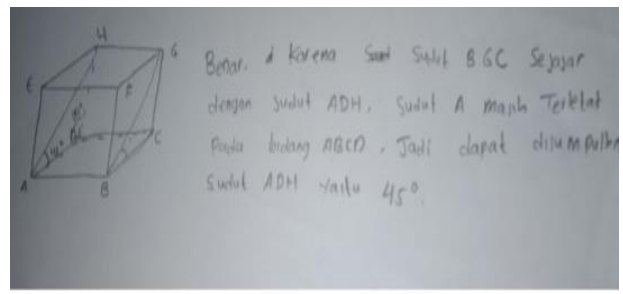

Based on the result of work number 8 , it is seen that subject 6 can already associate about the other line meaning the subject of 6 has started to control Level 3 (deduction) although not yet perfect.

\section{CONCLUSIONS}

Based on the results of the subject 5 and subject 6 that has high problem solving capabilities, they are able to master level 0 (visualization), Level 1 (Analysis), Level 2 (informal deduction) and have started to control Level 3 (deduction) Although not yet perfect .

\section{ACKNOWLEDGEMENTS}

Praise God almighty, for the presence of plenty of mercy and grace, so that the author can complete the research under the title: Analysis of Student Problem-Solving Ability Topics 3D Reviewed From Geometry Thinking Level.

His sincere appreciation and gratitude to his father and mother who has devoted all love and affection and attention to morals and material. May Allah Almighty always bestows mercy, health, gifts, and blessings in the world and the hereafter on the good favor that has been given to the author.

The award and thanks to researchers gave to Mrs. Sri Achyati, S. Pd., as the principal of the School of Islamic School of Secang, Mrs. Fadhilah Rahmawati, S. Pd., M. Pd., as a mentor lecturer who has assisted in the study. And thanks to colleagues who have helped in this research.
At the end of the word, researchers realize that in writing the research is still far from the word perfect. Therefore, researchers ask for advice and criticism that builds up to perfection and hopefully beneficial to us. Ameen.

\section{REFERENCES}

Argaswari DPAD. 2016. Development of learning modules based on Van Hiele's theory on quadrilles subjects to improve the geometry of thinking grade Vii SMPN 1 Selogiri. [Thesis]. University of the Eleven March.

Bieber C, Tuna A, \& Korkmaz S. 2013. The Mistakes and the Misconceptions of The Eighth Grade Students On The Subject of Angles. European Journal of Science and Mathematics Education, 1 (2), 50-59. Retrieved from scimath.net/articles/12/122.pdf.

Chairman Z. 2013. "Metakognisi's activity as one tool to improve students ' ability in solving mathematics problem", the Journal of Indonesian Mathematics Association, KNPM V. 2,013,652.

Ethan. 1983. Difficulty Learning Mathematics. Online.

Farida LN. 2018. Problem-solving ability seen from the theory Van Hiele students grade V Volume material cube and beam in $\mathrm{Sd} \mathrm{Hj}$ Isriati Baiturahman 2 School year 2017/2018. Whalesong State Islamic University Semarang.

Megita DP, Masduki. 2013. Improved problem-solving skills and mathematics learning creativity with the utilization of Core Math Tools (CMT) Software. National Seminar on mathematics Education, Surakarta, 119.

Razak F, Sutrino AB. 2017. Analysis of student thinking levels based on Van Hiele theory on 3D material reviewed from the cognitive style of the Dependent Field. Edumatica Volume 07 Number 02 October 2017, ISSN: 2088-2157.

Sholihah SZ, Afriansyah, EA. 2017. Student difficulty analysis in the process of solving geometry based on the thought phase of Van Hiele. Journal "Mosharafa", Volume 6, Number 2, May 2017.

Slameto. 2010. Learning and the factors that affect it. Jakarta: Rineka Cipta.

Suci, Rosyidi. 2012. Ability to solve students ' mathematical problems in learning problem posing group. MATHEdunesa, $1(2)$

Suherman. 2001. Contemporary mathematics Learning strategy. Bandung: UPL. 